\title{
The Otherness of Motherhood in the Selected Novels of Buchi Emecheta
}

\author{
Dasari Narendra Babu', SSVN. Sakunthala ${ }^{2}$ \\ ${ }^{1}$ Research Scholar, Acharya Nagarjuna University, Guntur, Andhra Pradesh \\ ${ }^{2}$ Dr. L. Bullayya College, Arts \& Science PG Block-6, Visakhapatnam
}

Corresponding Author: Dasari Narendra Babu

\begin{abstract}
This paper focuses on the role of women, especially the role of a mother during the pains of daughters. Deliberately or unknowingly mother often causes their female children deep scars in their lives and they remain perpetually. In consequence for that behavior, a girl child suffers at the hands of mother like figure, directly responsible for the upbringing, the protagonist metes out to her own girl child. The earlier African novels describe mother as Supreme Being and root of African culture, but in reality, the situations of women and mother like being are entirely different. The author brings out the hidden truth and exposes it to the world. The male authors focus on the positive aspects of motherhood and highlight the character of mother as a symbol of sacrifice and fertility. It is always shown as the mother character as an embodiment of all good qualities. However, Emecheta a careful observer of her culture and also a spectator of other cultures narrated the otherness of motherhood in her novels. In her earlier novels, she primarily focused on two aspects that is the otherness of motherhood and the oppressive elements of patriarchal society. This paper focuses on the otherness of motherhood in the novels of Buchi Emecheta.
\end{abstract}

Keywords: Motherhood, Patriarchal Society, Feminism, Otherness

\section{INTRODUCTION}

In the recent decades, the feministic perspective emerged as a strong movement and posed a multi angle ideology. The ideology of feminism is attributed to the globalization of the world, and changes occurred in various countries. The modern concept of feminism addresses the role of women in conservative and liberal societies. The feministic theory advocates that women are oppressed in various angles even though society is graceful and advanced. The major theme of Emecheta is women itself. She sees women in socio-cultural angles and economical perspectives. She also observes in her novels how such perspectives influence women and causes pain perpetually. In her novels, women suffer from other women, maybe they are the mother of the protagonist or women of other cultures or the same ethnic groups. In the novels of Buchi Emecheta mother figures are shown as they never understand their daughters to share the love that is vital between mother and daughter.

"Words said that she died not blessing me" 1

In Emecheta's life also the same type of conditions occurred. Emecheta believed that her mother never understood her. In her writings, the same kind of relationship occurs between women. After reading the Autobiography "Head Above Water", the reader does not surprise why she portrays such a relationship between mother and daughter. Emecheta deeply indulged with such themes and effectively depicted the vicious nature of women among them. The theme of maternal oppression of the girl child is a recurrent theme in her novels. A different phenomenon exists in Africa where women oppress their own kind, and suffer their 
daughters in the name of gender. The oppression of females begins in the home itself and it is continuing long lastingly. Another novelist Flora Nwapa, also makes same kind of observation

"the oppression of the woman starts in the home" (James 1990, P.113) ${ }^{2}$

In the African Culture begetting a male progeny is more important to prove as a woman. If a woman is barren or get one female child are almost equal. In the African literature, a recurrent theme would be a woman gives preference and oppresses her own sex in preference of male child. The autobiographical novel, Second Class Citizen depicts maternal oppression of female children in their homes. In the family a woman does not allow equal opportunities to girl and boy child. The kind of oppression causes unhappiness among girl children. A mother thwarts her children's opportunities deliberately if she belongs to the same gender. Adah's mother has no belief of female education and she does not care about Adah's education, before her brother, who is younger than Adah. The unhappiness of Adah is caused by her mother's opinion that Adah's mother is not willing to send her girl child and help her in domestic chores rather than being educated. Adah boldly walks into school. She does not care about her father canning, but she says about her mother behaviour

"Pa would be alright: he would probably cane her, you know just a few strokes - six or so, not much but Ma would not cane, she would smack and smack, and then nag and nag all day long."3

Adah identified her opposite gender that is her mother is her oppressor, due to the bad relationship prevailed between them. Adah's mother often complains that she is not at all cooperative. In the words of Adah

"would lie, just for the joy of lying; she took secret joy in disobeying her mother" (SCC, P.9)
Adah expresses the psychological oppression of her mother in a casual manner, as it is a common behavior in the African society. After her father's sudden demise, Adah's fortunes are reached to the lowest ebb, because her mother became her controller and she takes every decision for her. After acquainted all the situations Adah learns that her education is the only emancipator in her life. Adah's mother unwilling agrees to send her school further because she fetches more bride price and the amount can be utilized for her boy's education. Adah's mother always says that old men take more care of their women rather than youngsters.

"...because only they could afford the high bride - price' Ma was asking" (SCC, P.20).

Adah discovers that her mother is asking a big bride price so that money could be used to train her son, who not at all interested in education. The old people only fetch the bride price that Adah's mother is demanding. Adah's mother not only oppressed her domestically but also not allowing Adah to choose her husband among young people of her age. Surprisingly, the influence of her mother fell upon. After begetting child, she also considers preferring sons to daughters. When Vicky, fell ill and admitted at the hospital, nurse asks if the boy was her only son? His illness has affected her and Adah replies

"... there was another, but she was only a girl” (SCC, P.68)

As if girls are not children and if they were ill, they are suppose to die just like that. This kind of attitude keeps on wondering people why women, especially mothers continue to despise their own kind even when they are the victims of such attitude.

In the Joys of Motherhood, many instances depict women as being the oppressors of their female progeny. The otherness of Motherhood is close theme of Emecheta, has highlighted in this novel. 
Nnu Ego does not want to educate her daughters because

"...will have to leave and help me in running the house and in my trade". 4

The opinion of Nnu Ego clearly reflects the typical mindset of African mothers. One of the twin daughters of Nnu Ego, grumbles at the chores given to her and her twin sister Kehinde, replies that "The boys can help too" (P.175), but Nnu Ego replies in the typical African mother style

"They have to go to their lesson, Taiwo; and stop moaning. You are a girl, you know" (JM, P.175)

These type of incidents make girls so unhappy and curse their fate that they are born in a society where they want only boys, except at the time of their marriage.

The reply of Taiwo again perplexes the reader-

"I know that mother, you remind us all the time" (JM, P.175)

The girls of new Africa are fed up with such kind mother's treatment that she is not a boy, cannot enjoy the privileges but make hard work to end the meets. The treatment of mother keeps the girls in perpetual unhappiness. Emecheta always makes a note in her novels about the relationship of Ibuzan mothers and daughters. Emecheta sarcastically passes a remark through the character of Iyawo Itsekiri,

"You Ibos, is there nothing on this earth that you won't sell to make money? You would even sell your children if it were possible." (JM, P.175)

Callously Nnu Ego speaks "I do not intend to selling my children. But I wouldn't mind sending the girls somewhere to learn a trade if I would be given some money for their services"

"The money I'd get from them would help me in looking after others. Children sent away like that usually learn something, you know, good trade as well." (JM, P.No.175)
The word "Others" is nothing but boys. It is clearly implied that mothers are ready to oppress and daughters to inhumane and degrading circumstances, in order to maintain patriarchal society. The pathetic aspect is women who are subjected to inhuman treatment; again continue the same condition for their daughters.

In 'The Bride Price', Emecheta concentrates on the lack of bond between mother and daughter, as existed between daughter and father. Aku-nna is willing to get more bride price for her and make her father proud. But she

"... knew that there was a kind of bond between her and her father which did not exist between her and her mother",

Again this lack of bond between mother and daughter is the consequence of all the oppressions that the girl child undergoes in the home of her mother. During the time progresses, the lack of relationship between mother and daughter leads to lie and betrayal. Due to Aku-nna's father's demise, her mother and other property acquired by her father was possessed by Okonkwo, her ambitious uncle. Aku-nna and her mother shifted to Ibuza, where her mother quickly adopted to the place. Ma Blackie, Aku-nna's mother is eager to get a handsome bride price for her daughter to maintain her newly born son. But Aku-nna falls in love with an Osu, called Chike. As an outcaste, the entire family of Aku-nna rejected Chike. But Akunna firmly believed that her happiness lied in marrying Chike. Aku-nna started hating her mother when she is silent in such important situation of her daughter's life.

"...she was beginning to hate her mother for being so passive about it all" (BP, P.120).

Ma Blackie also cursed her child, cried aloud and swore her to die, as she bring disaster to the grace of family. This really devastated the spirits of Aku-nna and began to think that one's mother could ever become one's friend. Her mother is ready to use Chike as a ferry to pull through difficult 
period and not ready to accept him as her son-in-law. This sudden onset of thinking brought bitterness in the mind of Aku-nna. Thus, maternal oppression is an important factor in the life of a girl's child.

Girls began to either hate her mother or mother like character or adopt the same kind of behavior in their lives. Women by nature are not passive and they need certain push from their parents that too from their mother. These three novels lay emphasis on the culture of Africa, and how a girl is illtreated in the hands of their mother or mother like figure. In the age coming ceremonies mothers allow their daughter to be oppressed from patriarchal members. Male members may tease them with their brutal activities, and words. Certain times they touch their private parts also. This kind of behavior took in circular format. The women who become mothers in later parts of their lives think that the situation is common and has to adopt the behavior in patriarchal societies. Women are great helpers of themselves. Only a few writers like Emecheta, and Flora N'wapa reflected such insights in their writings.

\section{Acknowledgement: None}

\section{Conflict of Interest: None}

\section{REFERENCES}

1. Acholonu, Catherine O. Africa, the New Frontier: Towards a Truly Global Literary Theory for the $21 \mathrm{st}$ Century. Owerri, Nigeria: AFA, 2002
2. Acholonu, Catherine Obianuju. Motherism: the Afrocentric Alternative to Feminism. Owerri, Nigeria: Afa Publications, 1995.

3. Emecheta, Buchi. Head Above Water, London: Flemingo edition, Fontana Paperbacks, 1986.

4. Emecheta, Buchi. Second Class Citizen, London: Allison and Busby, 1974; New York: George Braziller, 1975.

5. Emecheta, Buchi. The Bride Price, London: Allison and Busby; New York: George Braziller, 1976

6. Emecheta, Buchi. The Joys of Motherhood, London: Allison and Busby; New York: George Braziller, 1979

7. Frank, Katherine. 'The Death of a Slave Girl: African Womahood in the novels of Buchi Emecheta.', World Literature Written in English. Vol.2, No.3, 1982.

8. James, Adeola. "Review of an Introduction to the African Novel by Eustace Palmer." African Literatures Today. Vol.7, 1975.

9. Okome O. Obituary: Buchi Emecheta (1944-2017). The Journal of Common wealth Literature. 2017;52(2):401-408.

10. Ward, Cynthia. "What They Told Buchi Emecheta: Oral Subjectivity and the Joys of 'Otherhood'. PMLA Vol.105, 1990, Pp.8397.

How to cite this article: Dasari Narendra Babu, SSVN. Sakunthala. The otherness of motherhood in the selected novels of Buchi Emecheta. Galore International Journal of Applied Sciences \& Humanities. 2021; 5(4): 811. DOI: https://doi.org/10.52403/gijash. 20211002 